\title{
PEMANFAATAN ISI PESAN INSTAGRAM DAN PERILAKU PEMILIHAN MAKANAN JAJANAN PADA REMAJA
}

\section{The Utilization of Instagram Message Contents and Behavior of Snack Choice in Teenagers}

\author{
Ravi Masitah ${ }^{1}$, Ni Putu Eny Sulistyadewi ${ }^{1}$ \\ 1Program Studi Ilmu Gizi, Fakultas IImu Kesehatan, Sains, dan Teknologi \\ Universitas Dhyana Pura, Bali. \\ E-mail: ravimasitah@undhirabali.ac.id
}

\begin{abstract}
Instagram is a medium that is widely used by teenagers to upload or search for various snacks menu information. The utilization of message contents will affect the behavior of snack choice. Applying good behavior can help teenagers to fulfill their nutritional needs but bad behavior can cause health problems. The study aims to analyze the effect of the utilization of Instagram message contents on the behavior of snack choice in teenagers. This research was quantitative descriptive with a cross-sectional design. The sample was 91 teenagers aged 14-16 years, the selection was by purposive sampling. Data were analyzed by using the chi-square test with SPSS. The results showed that there was a relationship between the use of Instagram message contents on the behavior of snack choice in teenagers with $p$-value $(0,000)<0.05$. Utilization of positive message content for health purposes to seek a variety of healthy snack food menu choices will have an impact on the behavior of selecting good snacks so that it leads to consuming these foods.
\end{abstract}

Keywords: instagram message, snack choice behavior, teenagers

\section{ABSTRAK}

Instagram adalah media yang banyak digunakan remaja untuk mengunggah atau mencari berbagai informasi menu makanan jajanan. Pemanfaatan isi pesan akan berpengaruh pada perilaku pemilihan makanan jajanan. Penerapan perilaku yang baik dapat membantu remaja memenuhi kebutuhan gizi namun perilaku yang tidak baik dapat menyebabkan masalah kesehatan. Penelitian bertujuan menganalisis hubungan pemanfaatan isi pesan Instagram terhadap perilaku pemilihan makanan jajanan pada remaja. Jenis penelitian adalah deskriptif kuantitatif dengan desain cross-sectional. Sampel penelitian sebanyak 91 remaja usia 14-16 tahun, pemilihan secara purposive sampling. Data dianalisis menggunakan uji Chi-square dengan SPSS. Hasil penelitian menunjukkan terdapat hubungan pemanfaatan isi pesan Instagram dengan perilaku pemilihan makanan jajanan pada remaja $p$-value $(0,000)$ $<0,05$. Pemanfaatan isi pesan yang positif dengan tujuan kesehatan untuk mencari berbagai macam pilihan menu makanan jajanan sehat akan berdampak pada perilaku pemilihan makanan jajanan yang baik sehingga menuntun untuk turut mengonsumsi makanan tersebut.

Kata kunci: pesan Instagram, perilaku pemilihan makanan jajanan, remaja 


\section{PENDAHULUAN}

$\mathrm{R}$ emaja mengalami periode pertumbuhan dan perkembangan yang cepat dan merupakan periode kritis terjadinya perubahan perilaku yang berkaitan dengan kesehatan seperti pemilihan makanan dan aktivitas fisik. ${ }^{1}$ Perilaku gizi yang sehat pada remaja sangat penting dan akan bertahan pada usia dewasa. $^{2}$

Hasil Pemantauan Status Gizi (PSG) pada tahun 2017 menunjukkan prevalensi remaja kurus usia 13-15 tahun dan 16-18 tahun secara nasional masing-masing sebesar 6,7 persen dan 3,0 persen sedangkan prevalensi remaja sangat kurus masing-masing sebesar 2,6 persen dan 0,9 persen. Provinsi Bali mempunyai 0,7 persen remaja usia 13-15 tahun dengan status gizi sangat kurus dan 3,9 persen kurus sedangkan pada remaja usia 16-18 tahun 0,5 persen sangat kurus dan 2,5 persen kurus. ${ }^{3}$ Hasil skrining status gizi pada 13,269 remaja SMA/SMK/MA di kota Denpasar tahun 2018 menunjukkan remaja dengan status gizi gemuk sebesar 4,51 persen, obesitas 0,66 persen, sangat kurus 0,05 persen, dan kurus 2,58 persen. ${ }^{4}$ Angka tersebut menunjukkan masih terdapat masalah gizi pada remaja di Kota Denpasar. Kesehatan pada masa remaja sangat penting diperhatikan karena berpengaruh terhadap kesehatan saat dewasa dan generasi berikutnya. ${ }^{5}$

Obesitas pada remaja dapat menyebabkan kesulitan pernapasan, peningkatan risiko patah tulang, hipertensi, penyebab penyakit kardiovaskular, resistensi insulin dan efek psikologis. ${ }^{6}$ Gizi kurang pada remaja dapat menyebabkan peningkatan risiko terkena penyakit infeksi. $^{7}$

Makanan yang bergizi dan aman merupakan kunci penting untuk mendukung kesehatan. Kebiasan makan remaja secara umum buruk karena rendahnya konsumsi sayur dan buah dan meningkatnya konsumsi makanan yang tinggi kandungan energi. ${ }^{8}$ Makanan jajanan dapat menjadi alternatif dari kurangnya konsumsi makanan utama untuk pemenuhan kebutuhan zat gizi. ${ }^{9}$

Penerapan perilaku yang baik dalam memilih makanan jajanan sehat dapat meningkatkan status kesehatan sedangkan perilaku yang tidak baik dapat menjadi masalah karena akan menyebabkan seseorang terbiasa mengonsumsi makanan jajanan yang tidak sehat. ${ }^{10}$ Berdasarkan hasil penelitian sebagian besar remaja cenderung mengakses informasi kesehatan melalui media sosial. ${ }^{11}$ Media memiliki pengaruh besar terhadap perilaku pemilihan makanan jajanan. Berbagai penyebaran informasi kesehatan melalui media sosial telah umum dilakukan, misalnya 1 dari 9 pengguna media sosial mempromosikan kesehatan di akun mereka masing-masing. ${ }^{12}$

Instagram adalah media sosial yang popular dan dapat digunakan sebagai media promosi makanan melalui foto ataupun video..$^{13}$ Beberapa pengguna Instagram memposting makanan dengan tujuan kesehatan dan menggunakannya untuk mencari berbagai macam pilihan makanan sehat. ${ }^{14}$

Penggunaan Instagram yang tidak tepat akan menimbulkan dampak negatif bagi kesehatan. Hasil penelitian menunjukkan bahwa promosi makanan di media sosial dengan kandungan tinggi lemak, tinggi gula dan tinggi garam lebih banyak diminati daripada makanan sehat. Hal ini memiliki implikasi promosi makanan yang tidak sehat sehingga akan berdampak buruk bagi kesehatan. ${ }^{15}$

Berdasarkan latar belakang tersebut maka diperlukan penelitian untuk dapat mengetahui hubungan pemanfaatan isi pesan Instagram terhadap perilaku pemilihan makanan jajanan pada remaja.

\section{METODE PENELITIAN}

Jenis penelitian adalah deskriptif kuantitatif dengan desain cross-sectional. Populasi adalah siswa-siswi kelas X SMK Kesehatan Bali Dewata Denpasar. Pemilihan populasi terjangkau penelitian ditentukan berdasarkan hasil skrining data status gizi remaja SMA/SMK/MA kota Denpasar pada tahun 2018. Sekolah tersebut terpilih karena di bawah wilayah kerja puskesmas Denpasar Utara yang memilki jumlah remaja dengan status gizi normal terendah. Perhitungan besar sampel menggunakan rumus Slovin diperoleh sampel sebanyak 91 remaja usia 14-16 tahun. Pemilihan sampel penelitian dilakukan secara purposive sampling berdasarkan kriteria inklusi dan ekslusi yang telah ditetapkan peneliti. Siswa-siswi yang sesuai dengan kriteria tersebut dapat dinyatakan sebagai sampel penelitian. 
Kriteria inklusi:

1) Siswa-siswi usia 14-16 tahun

2) Siswa-siswi yang memiliki smartphone pribadi

3) Siswa-siswi yang memiliki akun aktif media sosial berupa Instagram

4) Siswa-siswi yang mengikuti minimal 2 akun Instagram yang berkaitan dengan gizi dan kesehatan

5) Siswa-siswi yang mengikuti minimal 2 akun Instagram yang berkaitan dengan kuliner dan fast food

6) Siswa-siswi yang tinggal bersama orang tua/keluarga

7) Siswa-siswi yang bersedia menandatangani informed consent

Kriteria ekslusi:

1) Siswa-siswi yang tidak mengikuti keseluruhan rangkaian kegiatan penelitian

2) Siswa-siswi yang sedang melakukan diet penurunan/penambahan berat badan

3) Siswa-siswi yang vegetarian

4) Siswa-siswi yang menderita penyakit yang mengharuskan menjalankan diet tertentu (diabetes, ginjal, jantung, kanker, hipertensi)

Variabel bebas penelitian adalah pemanfaatan isi pesan berupa jenis unggahan yang sering dikunjungi pada laman Instagram mulai dari jenis makanan jajajanan sehat hingga tidak sehat. Variabel terikat adalah perilaku pemilihan makanan jajanan pada remaja. Unggahan pada laman Instagram menuntun remaja untuk memilih mengonsumsi makanan jajanan sesuai dengan ketertarikannya. Penentuan kedua variabel tersebut dilakukan dengan menggunakan kuesioner yang diisi oleh sampel penelitian. Kuesioner pemanfaatan isi pesan Instagram menggambarkan bagaimana sampel penelitian mencari, membaca dan berbagi informasi berkaitan dengan pilihan jenis makanan jajanan yang dikunjunginya pada laman Instagram. Kuesioner perilaku pemilihan makanan jajanan menggambarkan bagaimana sampel penelitian memilih dan mengonsumsi berbagai pilihan jenis makanan jajanan.
Kuesioner sebelumnya telah dilakukan uji validitas dan reliabilitas. Hasil uji menunjukkan terdapat 14 butir soal valid dengan nilai reliabilitas 0,849 untuk kuesioner pemanfaatan isi pesan dan 15 soal valid dengan nilai reliabilitas 0,883 untuk kuesioner perilaku pemilihan makanan jajanan.

Jawaban yang disediakan terdiri dari setuju dan tidak setuju. Skor 1 jika pernyataan tepat dan 0 jika tidak tepat. Total skoring untuk kuesioner pemanfaatan isi pesan Instagram dikategorikan positif jika $\geq 42$ persen dan negatif $<42$ persen sedangkan kuesioner perilaku pemilihan makanan jajanan dikategorikan baik $\geq 60$ persen dan tidak baik $<60$ persen. Penentuan tersebut menggunakan rumus interval yaitu range dibagi jumlah kategori. Range diperoleh dari selisih skor nilai tertinggi dan terendah sampel penelitian yang telah dikalikan dengan jumlah soal.

Pengolahan dan analisis data dilakukan secara univariat dan bivariat menggunakan program komputer SPSS. Analisis univariat digunakan untuk melihat gambaran karakteristik umum sampel penelitian yaitu usia, jenis kelamin dan status gizi. Analisis bivariat digunakan untuk mengetahui hubungan pemanfaatan isi pesan Instagram terhadap perilaku pemilihan makanan jajanan pada remaja dengan melakukan uji Chi-Square. Penelitian ini telah memperoleh persetujuan ethical clearance dari Komisi Etik Penelitian (KEP) Fakultas Kedokteran Universitas Udayana/Rumah Sakit Umum Pusat Sanglah Denpasar No.2019.02.2.1013.

\section{HASIL}

\section{Karakteristik sampel penelitian}

Karakteristik sampel penelitian ditunjukkan pada Tabel 1. Sebagian besar sampel penelitian berusia 15 tahun $(75,8 \%)$, jenis kelamin perempuan $(90,1 \%)$, tinggal di wilayah pedesaan $(58,2 \%)$, telah mengikuti akun gizi dan kesehatan serta akun kuliner dan fast food selama $>6$ bulan masing-masing 44 persen dan 56 persen. 
Tabel 1

Karakteristik Sampel Penelitian

\begin{tabular}{lcc}
\hline Karakteristik & $\mathrm{n}$ & $\%$ \\
\hline Usia & 11 & 12,1 \\
14 tahun & 69 & 75,8 \\
15 tahun & 11 & 12,1 \\
16 tahun & & \\
Jenis kelamin & 9 & 9,9 \\
Laki-laki & 82 & 90,1 \\
Perempuan & & \\
Tempat tinggal & 53 & 58,2 \\
Pedesaan & 38 & 41,8 \\
Perkotaan & & \\
Lama mengikuti akun gizi dan kesehatan & 24 & 26,4 \\
$<3$ bulan & 27 & 29,7 \\
3-6 bulan & 40 & 44,0 \\
$>6$ bulan & & \\
Lama mengikuti akun fast food dan kuliner & 12 & 13,2 \\
$<3$ bulan & 28 & 30,8 \\
3-6 bulan & 51 & 56,0 \\
\hline 6 bulan & & \\
\hline
\end{tabular}

Hasil penelitian menunjukkan terdapat 69 akun Instagram yang berkaitan dengan gizi dan kesehatan yang diikuti oleh sampel penelitian. Sebagian besar akun tersebut menampilkan tips pola makan sehat didukung oleh contoh menu, resep, manfaat mengonsumsi dan kandungan zat gizi makanan. Sedangkan terdapat 76 akun Instagram yang berkaitan dengan kuliner dan fast food yang diikuti oleh sampel penelitian. Sebagian besar akun tersebut menampilkan menu makanan cepat saji, makanan dan minuman manis, dan makanan pedas dalam porsi besar.

\section{Pemanfaatan isi pesan Instagram dan perilaku pemilihan makanan jajanan pada remaja}

Hasil penelitian berdasarkan pernyataan pada kuesioner dapat dilihat pada Tabel 2 dan Tabel 3. Sebagian besar sampel penelitian dapat mencari dan membaca berbagai jenis pilihan menu makanan jajanan sehat dan tidak sehat namun kandungan zat gizi dari makanan tersebut masih belum banyak diketahui karena tidak terdapat dalam unggahan. Sebagian besar sampel penelitian telah memilih untuk membeli dan mengonsumsi makanan jajanan berdasarkan informasi yang telah diketahui dan ketertarikan terhadap unggahan makanan tersebut.

Berdasarkan hasil uji bivariat terdapat hubungan pemanfaatan isi pesan Instagram dengan perilaku pemilihan makanan jajanan pada remaja dengan nilai $p$-value $(0,000)<0,05$. Tabel 4 menunjukkan bahwa sampel penelitian yang memanfaatkan isi pesan dengan negatif sebagian besar memiliki perilaku pemilihan makanan jajanan yang tidak baik $(62,5 \%)$ sedangkan sampel penelitian yang memanfaatkan isi pesan dengan positif sebagian besar memiliki perilaku pemilihan makanan jajanan yang baik $(89,3 \%)$. 
Tabel 2

Analisis Kuesioner Penelitian Pemanfaaatan Isi Pesan Instagram

\begin{tabular}{|c|c|c|c|c|c|}
\hline \multicolumn{2}{|r|}{ Pernyataan } & \multicolumn{2}{|c|}{ Positif } & \multicolumn{2}{|c|}{ Negatif } \\
\hline & & $\mathrm{n}$ & $\%$ & $\mathrm{n}$ & $\%$ \\
\hline 1 & $\begin{array}{l}\text { Saya selalu membaca informasi kesehatan yang muncul di } \\
\text { beranda Instagram sava }\end{array}$ & 55 & 60,4 & 36 & 39,6 \\
\hline 2 & $\begin{array}{l}\text { Saya dapat mencari berbagai macam pilihan makanan dan } \\
\text { minuman sehat melalui akun kesehatan dan gizi yang saya ikuti }\end{array}$ & 89 & 97,8 & 2 & 2,2 \\
\hline 3 & $\begin{array}{l}\text { Instagram membantu saya menentukan pilihan pada jenis } \\
\text { makanan dan minuman sehat yang akan saya konsumsi }\end{array}$ & 72 & 79,1 & 19 & 20,9 \\
\hline 4 & $\begin{array}{l}\text { Saya dapat mencari manfaat konsumsi makanan dan minuman } \\
\text { sehat melalui akun kesehatan dan gizi yang saya ikuti }\end{array}$ & 87 & 95,6 & 4 & 4,4 \\
\hline 5 & $\begin{array}{l}\text { Saya dapat mencari informasi kandungan zat gizi dalam makanan } \\
\text { dan minuman sehat melalui akun kesehatan dan gizi yang saya } \\
\text { ikuti }\end{array}$ & 24 & 26,4 & 67 & 73,6 \\
\hline 6 & $\begin{array}{l}\text { Instagram membantu saya menambah wawasan mengenai gizi } \\
\text { dan kesehatan }\end{array}$ & 74 & 81,3 & 17 & 18,7 \\
\hline 7 & $\begin{array}{l}\text { Saya sering berinteraksi dengan pengguna Instagram lainnya } \\
\text { berkaitan dengan makanan jajanan sehat }\end{array}$ & 59 & 64,8 & 32 & 35,3 \\
\hline 8 & $\begin{array}{l}\text { Saya selalu membaca iklan fast food yang muncul di beranda } \\
\text { Instagram saya }\end{array}$ & 15 & 16,5 & 76 & 83,5 \\
\hline 9 & $\begin{array}{l}\text { Saya dapat mencari berbagai macam pilihan menu fast food } \\
\text { melalui akun fast food dan kuliner yang saya ikuti }\end{array}$ & 4 & 4,4 & 87 & 95,6 \\
\hline 10 & $\begin{array}{l}\text { Instagram membantu saya menentukan pilihan menu fast food } \\
\text { yang akan saya konsumsi }\end{array}$ & 5 & 5,5 & 86 & 94,5 \\
\hline 11 & $\begin{array}{l}\text { Saya dapat mencari kandungan zat gizi menu fast food melalui } \\
\text { akun fast food dan kuliner yang saya ikuti }\end{array}$ & 0 & 0 & 91 & 100 \\
\hline 12 & $\begin{array}{l}\text { Saya dapat mengetahui dampak konsumsi fast food melalui akun } \\
\text { fast food dan kuliner yang saya ikuti }\end{array}$ & 0 & 0 & 91 & 100 \\
\hline 13 & $\begin{array}{l}\text { Instagram membantu saya lebih banyak mengetahui jenis fast } \\
\text { food }\end{array}$ & 56 & 61,5 & 35 & 38,5 \\
\hline 14 & $\begin{array}{l}\text { Saya sering berinteraksi dengan pengguna Instagram lainnya } \\
\text { berkaitan dengan fast food }\end{array}$ & 61 & 67 & 30 & 33 \\
\hline
\end{tabular}


Tabel 3

Analisis Kuesioner Penelitian Perilaku Pemilihan Makanan Jajanan

\begin{tabular}{|c|c|c|c|c|c|}
\hline & \multirow{2}{*}{ Pernyataan } & \multicolumn{2}{|c|}{ Baik } & \multicolumn{2}{|c|}{ Tidak baik } \\
\hline & & $\mathrm{n}$ & $\%$ & $\mathrm{n}$ & $\%$ \\
\hline 1 & Saya memilih makanan jajanan yang bersih dan tertutup & 67 & 76,3 & 24 & 26,4 \\
\hline 2 & Saya membeli makanan jajanan yang tidak berbau atau busuk & 76 & 83,5 & 15 & 16,5 \\
\hline 3 & $\begin{array}{l}\text { Saya lebih menyukai konsumsi makanan jajanan yang } \\
\text { mengandung pemanis buatan }\end{array}$ & 59 & 64,8 & 32 & 35,2 \\
\hline 4 & Saya memilih makanan jajanan yang berwarna-warni mencolok & 51 & 56 & 40 & 44 \\
\hline 5 & $\begin{array}{l}\text { Saya mengonsumsi makanan jajanan yang mengandung banyak } \\
\text { penyedap rasa dan pengawet }\end{array}$ & 69 & 75,8 & 22 & 24,2 \\
\hline 6 & $\begin{array}{l}\text { Saya memilih makanan jajanan yang banyak mengandung lemak } \\
\text { dan minyak }\end{array}$ & 67 & 73,6 & 24 & 26,4 \\
\hline 7 & $\begin{array}{l}\text { Saya memilih mengonsumsi makanan jajanan yang mengandung } \\
\text { gizi lengkap }\end{array}$ & 74 & 81,3 & 17 & 18,7 \\
\hline 8 & $\begin{array}{l}\text { Saya lebih memilih mengonsumsi minuman berwarna dan } \\
\text { bersoda dibandingkan air putih }\end{array}$ & 79 & 86,8 & 12 & 13,2 \\
\hline 9 & $\begin{array}{l}\text { Saya membiasakan diri membaca kandungan zat gizi pada } \\
\text { kemasan makanan jajanan }\end{array}$ & 65 & 71,4 & 26 & 28,6 \\
\hline 10 & $\begin{array}{l}\text { Saya sering mengonsumsi fast food karena dikemas secara } \\
\text { menarik dan hygienis }\end{array}$ & 46 & 50,5 & 45 & 49,5 \\
\hline 11 & $\begin{array}{l}\text { Saya sering mengonsumsi fast food karena kandungan energy } \\
\text { yang tinggi }\end{array}$ & 64 & 70,3 & 27 & 29,7 \\
\hline 12 & Saya menghindari konsumsi fast food untuk mencegah obesitas & 66 & 72,5 & 25 & 27,5 \\
\hline 13 & Saya dan teman-teman mengonsumsi fast food saat berkumpul & 58 & 63,7 & 33 & 36,3 \\
\hline 14 & $\begin{array}{l}\text { Saya dan teman-teman sering mengonsumsi fast food karena } \\
\text { terlihat lebih keren dan gaul }\end{array}$ & 15 & 16,5 & 76 & 83,5 \\
\hline 15 & $\begin{array}{l}\text { Saya sering mengonsumsi fast food karena paket promosi yang } \\
\text { ditawarkan }\end{array}$ & 19 & 20,9 & 72 & 79,1 \\
\hline
\end{tabular}

Tabel 4

Pemanfaatan Isi Pesan Instagram dan Perilaku Pemilihan Makanan Jajanan pada Remaja

\begin{tabular}{lccccc}
\hline \multirow{3}{*}{ Pemanfaatan isi pesan } & \multicolumn{5}{c}{ Perilaku pemilihan makanan jajanan } \\
\cline { 2 - 5 } & \multicolumn{4}{c}{ Baik } & \multicolumn{3}{c}{ Tidak baik } & \multirow{2}{*}{$p$} \\
\cline { 2 - 5 } & $\mathrm{n}$ & $\%$ & $\mathrm{n}$ & $\%$ & \multirow{2}{*}{$0,000^{\mathrm{a}}$} \\
\hline Negatif & 8 & 10,7 & 10 & 62,5 & \multirow{2}{*}{ Positif } \\
\hline
\end{tabular}

Uji Chi-Square

\section{BAHASAN}

Hasil analisis bivariat menunjukkan terdapat hubungan pemanfaatan isi pesan Instagram dengan perilaku pemilihan makanan jajanan pada remaja $p$-value $(0,000)<0,05$. Perilaku pemilihan makanan jajanan yang baik pada remaja cenderung dimiliki oleh mereka yang memanfaatkan isi pesan Instagram secara positif.
Penelitian ini sejalan dengan hasil penelitian sebelumnya yang menunjukkan bahwa terdapat korelasi erat antara variabel Food blogger terhadap pemilihan kuliner makanan sehat konsumen sebesar 0,486 . Hasil signifikansi pada uji T kurang dari 0,05 (0,002 dan $0,000<0,05)$ maka Ho ditolak. Artinya konten food blogger berpengaruh terhadap pemilihan kuliner makanan sehat. Persentase pengaruh variabel food 
blogger terhadap pemilihan kuliner makanan sehat sebesar 23,6 persen. Konten food blogger menjadi informasi produk yang akan disampaikan ke pengguna sosial media atau sebutan dalam Instagram yaitu follower yang membaca. Sehingga mempengaruhi perilaku mereka dalam memilih kuliner makanan sehat. ${ }^{16}$

Kebutuhan gizi pada masa remaja meningkat seiring dengan proses pertumbuhan dan perkembangan yang cepat. Oleh karena itu, pemenuhan kebutuhan gizi pada masa remaja menjadi sangat penting. Remaja adalah masa terjadinya transisi dari masa anak-anak menuju dewasa. Berbagai perubahan yang terjadi pada remaja salah satunya adalah perubahan perilaku dalam memilih jenis makanan. ${ }^{17}$ Remaja memasuki periode indenpendensi yaitu mereka memiliki kebebasan dalam memilih makanan yang disukainya. Sebagian besar pemilihan makanan tidak berdasarkan kandungan zat gizi namun hanya untuk kesenangan dan status sosial. ${ }^{18}$ Faktanya remaja cenderung melakukan diet yang salah, melewatkan makan pagi, lebih sering mengonsumsi makanan ringan, makanan cepat saji, minuman manis, dan kurang mengonsumsi sayur dan buah. ${ }^{19}$

Perilaku adalah faktor penting untuk meningkatkan derajat kesehatan. ${ }^{20}$ Media sosial telah terbukti secara signifikan mempengaruhi perilaku kesehatan pada berbagai kelompok usia. Remaja merupakan kelompok sasaran yang sangat tepat menggunakan media sosial sebagai media pembelajaran perubahan perilaku kesehatan. ${ }^{21}$ Media sosial sering menampilkan penggunanya yang sedang mengunjungi restoran, berbagi pengalaman mengonsumsi makanan dan merekomendasikan makanan tersebut di akun media sosial mereka. ${ }^{22}$ Instagram adalah jenis media sosial yang popular. Instagram dapat menyajikan secara menarik berbagai gambar makanan, mulai dari makanan sehat satupun tidak sehat. 23

Makanan jajanan adalah berbagai jenis olahan makanan dan minuman yang dijual dan disajikan sebagai makanan siap santap. Umumnya makanan jajanan yang disukai adalah makanan dengan warna, tekstur, aroma, suhu dan tampilan yang menarik. 24

Pemanfaatan pesan Instagram yang positif dapat membantu penggunanya lebih memperhatikan ukuran porsi, manfat konsumsi makanan dan meningkatkan asupan makan. ${ }^{25}$ Makanan jajanan memberikan kesempatan untuk kita dapat memilih berbagai menu makanan sehat. Konsumsi makanan jajanan diantara waktu makan utama dapat membantu memenuhi kebutuhan gizi. ${ }^{26}$ Pemenuhan kebutuhan gizi pada remaja sangat penting untuk pertumbuhan dan perkembangan yang optimal. ${ }^{27}$

Pemanfaatan pesan Instagram yang negatif misalnya dari berbagai unggahan makanan yang mengandung tinggi kalori dan lemak. Unggahan dengan tampilan yang menarik dan ditambahkan keterangan yang menunjukkan kelezatan makanan dapat menyebabkan pengguna lain turut mengonsumsi makanan tersebut dan memberikan implikasi promosi makanan yang tidak sehat. ${ }^{28}$

Kandungan lemak dan karbohidrat yang tinggi pada makanan jajanan merupakan penyumbang energi yang signifikan. Kualitas makanan jajanan dan frekuensi mengonsumsi makanan tersebut memberikan pengaruh buruk pada kesehatan. ${ }^{29}$ Konsumsi makanan jajanan yang tidak sehat yang mengandung tinggi kalori dengan porsi besar dapat menyebabkan obesitas. ${ }^{30}$ Obesitas pada remaja dapat meningkatkan risiko terjadinya penyakit seperti diabetes mellitus, hipertensi dan penyakit kardiovaskular pada saat dewasa. ${ }^{31}$

Media sosial khususnya Instagram dapat digunakan sebagai media pendidikan gizi pada remaja. Hal ini berkaitan dengan penggunaannya yang mudah dan tidak terbatas ruang dan waktu sehingga dapat menghemat biaya pendidikan gizi secara konvensional seperti penyuluhan. Penelitian ini menggambarkan dampak akun Instagram secara umum tidak spesifik pada satu akun. Penelitian selanjutnya diharapkan dapat mengintervensi satu akun yang menjadi acuan sehingga sampel penelitian dapat memperoleh pesan yang sama pada unggahan.

\section{SIMPULAN DAN SARAN}

\section{Simpulan}

Ada hubungan pemanfaatan isi pesan Instagram dengan perilaku pemilihan makanan jajanan pada remaja. Pemanfaatan isi pesan yang positif berhubungan dengan perilaku yang baik terhadap pemilihan makanan jajanan. 


\section{Saran}

Sebaiknya remaja memanfaatkan isi pesan Instagram secara positif sehingga terbentuk perilaku yang baik terhadap pemilihan makanan jajanan. Pemilihan makanan jajanan yang sehat akan berpengaruh pada pemenuhan kebutuhan gizi untuk pertumbuhan dan perkembangan tubuh yang optimal pada masa remaja.

\section{UCAPAN TERIMA KASIH}

Penulis mengucapkan terima kasih kepada SMK Kesehatan Bali Dewata, Universitas Dhyana Pura Bali dan semua pihak yang telah membantu.

\section{RUJUKAN}

1. Maehara M, Rah JH, Roshita A, Suryantan J, Rachmadewi A, Izwardy D. Patterns and risk factors of double burden of malnutrition among adolescent girls and boys in Indonesia. Plose One. 2019;14(8):1-15 (doi :https://doi.

org/10.1371/journal.pone.0221273).

2. Lopez PG, Oliver AS, Ries F, and Jurado JAG. Mediterranean diet, physical fitness and body composition in sevillian adolescents: a healthy lifestyle. Nutrients. 2019;11(9):2-14 (doi 10.3390/nu11092009).

3. Kemenkes RI. Buku saku pemantauan status gizi tahun 2017. Jakarta; 2017.

4. Dinas Kesehatan Kota Denpasar. Profil kesehatan kota Denpasar tahun 2018. 2018. Denpasar; 2018.

5. Sweeny K, Friedman HS., Sheehan P,

Fridman DP, Shi HA health system based investment case for adolescent health. Journal of Adolescent Health.. 2019; 65 : s8-s15. (doi

https://doi.org/10.1016/j.jadohealth.2019.03 .023).

6. Medeiros GC, Azevedo K, Garcia DA, Segundo VH, Mata AN, Siqueira KS, Fernandes AK, Santos RP, Trindade DD, Lyra CO, Piuvezam G. Protocol for systematic reviews of school-based food and nutrition education intervention for adolescent health promotion. Medicine. 2019; $\quad$ 98(35):1-6 (doi: 10.1097/MD.0000000000016977).

7. Irdiana W, Nindya TS. Hubungan kebiasaan sarapan dan asupan zat gizi dengan status gizi siswi SMAN 3 Surabaya. Amerta Nutr. 2017;1(3):227-235 (doi : 10.2473/amnt.v1i3.2017.227-235).

8. Roth S, Gill M, Puri S, Golston AC, Crespi CM, Albert SL, Rice LN, Prelip ML. Nutrition campaign knowledge and dietary behavior in middle school students. Calif $\mathrm{J}$ Health Promot. 2018;16(2):1-10 (doi:10.32398/cjhp. v16i2.2086).

9. Rakhman AF, Taufiqurrahman. Hubungan kebiasaan melewatkan sarapan dan pemilihan jajanan dengan kejadian wasting di Desa Sembung, Kecamatan Wringinanom, Kabupaten Gresik. Amerta Nutr. 2018; 2(3):237-244 (doi : 10.2473/amnt.v2i3.2018.237-244).

10. Dewi TL, Virianita R. Hubungan antara keterdedahan tayangan iklan komersial makanan ringan dan dukungan sosial dengan perilaku jajan anak. Jurnal Sains Komunikasi dan Pengembangan Masyarakat. 2018: 2 (2): 181-194 (doi : doi.org/10.29244/jskpm.2.2.181-194).

11. Pilgrim K, Joschko SB. Selling health and happiness how influencers communicate on Instagram about dieting and exercise: mixed methods research. BMC Public Health. 2019;19:1-9 (doi: 10.1186/s12889019-7387-8).

12. Nabi RL, Huskey R, Nichollsa SB, Keblusek $L$, Reed M. When audiences become advocates: Self-induced behavior change through health message posting in social media. Computers in Human Behavior. 2019; 99:260-267 (doi 10.1016/j.chb.2019.05.030).

13. Saboia I, Almeida AM, Sousa P, Pernencar C. I am with you: a netnographic analysis of the Instagram opinion leaders on eating behavior change. Procedia Computer Science. 2018;138:97-104 (doi : 10.1016/j.procs. 2018.10.014). 
14. Chung CF, Agapie E, Schroeder J, Mishra $S$, Fogarty J, Munson SA. When Personal tracking becomes social: examining the use of Instagram for healthy eating. Proceedings of the SIGCHI conference on human factors in computing systems. $\mathrm{CHI}$ Conference. 2017:1674-1687 (doi:10.1145/3025453. 3025747).

15. Coates AE, MPhil, Hardman CA, Halford JC, Christiansen P, Boyland EJ. Social media influencer marketing and children's food intake: a randomized trial. PEDIATRICS. 2019; 143(4):1-11 (doi :10.1542/peds.2018-2554).

16. Kusumaningrum DA, Wachyuni SS, Nathania $S$. The influence of blogger food content inselecting healty culinary. Tourism Scientific Journal. 2019; 4 (2):168-185 (doi : 10.32659/tsj.v4i2.57).

17. Hendra P, Suhadi R, Maria D, Heru C. Sayur bukan menjadi preferensi makanan remaja di Indonesia. Jurnal Kedokteran Brawijaya. 2019; 30 (4):331-335 (doi : 10.21776/ub.jkb.2019.030.04.18).

18. Laenggeng $H$, Lumalang $Y$. Hubungan pengetahuan gizi dan sikap memilih makanan jajanan dengan status gizi siswa SMP N1 Palu. Jurnal Kesehatan Tadulako. 2015;1 (1): 49-57 (doi : 10.2030/.v1i1.5733).

19. Corkins MR, Daniels SR, Ferranti SD, Golden NH, Kim JH, Magge SN, Schwarzenberg SJ. Nutrition in children and adolescents. Med Clin N Am. 2016; 100:1217-1235 (doi

10.1016/j.mcna.2016.06.005).

20. Iklima N. Gambaran pemilihan makanan jajanan pada anak usia sekolah dasar. Jurnal Keperawatan BSI. 2017;5 (1): 8-17 (doi : 10.31311/.v5i1.1774).

21. Frazier JP, Cochrane $K$, Mitrovich $C$, Pascual M, Buscaino E, Eaton L, Panlasigui N, Clopp B, Malik F. Using Instagram as a modified application of photovoice for storytelling and sharing in adolescents with type 1 diabetes. Qual Health Res. 2015; 25(10):1372-1382 (doi : 10.1177/1049732315583282).
22. Jin SV. Interactive effects of Instagram foodies' hashtagged \#foodporn and peer users' eating disorder on eating intention, envy, parasocial interaction, and online friendship. Cyberpsychology, Behavior, And Social Networking. 2018; 21 (3): 157-167 (doi : 10.1089/cyber. 2017.0476)

23. Allen B, Dodson R, Zuercher Z. Painting a global picture of health: use of Instagram to portray \#healthyfoods vs \#unhealthyfoods. Journal of Nutrition Education and Behavior. 2018;50 (7): 58 (doi : 10.1016/j.jneb.2018.04.135).

24. Rahayu S, Refirman, Sari DR. Hubungan pengetahuan tentang zat aditif dengan sikap pemilihan makanan jajanan siswa SMPN 74 Jakarta. Jurnal Pendidikan Biologi. 2016;9 (2): 45-53 (doi : 10.21009/biosferjpb.9-2.7).

25. Maria DS, Alssafi A, Coccia C. The food selfie project: eating behaviors of dietetic students through the use of Instagram. Journal of The Academy of Nutrition And Dietetics. 2017;117 (9): 65 (doi : 10.1016/j.jand.2017.06.203).

26. Bucher T, Collins C, Diem S, Siegrist M. Adolescents' perception of the healthiness of snacks. Food Quality and Preference. 2016; 50:94-101 (doi 10.1016/j.foodqual.2016.02.001).

27. Novita R. Hubungan status gizi dengan gangguan menstruasi pada remaja putri di SMA Al-Azhar Surabaya. Amerta Nutr. 2018;2 (2): 172-181 (doi 10.2473/amnt.v2i2.2018.172-181).

28. Holmberg C, Chaplin JE, Hillman T, Berg C. Adolescents' presentation of food in social media: An explorative study. Appetite. 2016;99:121-129 (doi 10.1016/j.appet.2016.01.009)

29. Xue H, Maguire RL, Liu J, Kollins SH, Murphy SK, Hoyo C, Fuemmeler BF. Snacking frequency and dietary intake in toddlers and preschool children. Appetite. 2019;142:1-7 (doi 10.1016/j.appet.2019.104369).

30. Mattes RD. Snacking: A cause for concern. Physiology \& Behavior. 2018;279-283 (doi : 10.1016/j.physbeh.2018.02.010). 
31. Branco BH, Valladares D, Oliveira FN, Carvalho IZ, Marques DC, Coelho2 AA, Oliveira LP, Bertolini SM. Effects of the order of physical exercises on body composition, physical fitness, and cardiometabolic risk in adolescents participating in an interdisciplinary program focusing on the treatment of obesity. Frontiers in Physiology. 2019;10:1-11 (doi : 10.3389/fphys. 2019.01013). 